\title{
КРИТЕРІЇ МЕДІАБЕЛЬНОСТІ В КОНТЕКСТІ СИСТЕМИ ВИРІШЕННЯ СПОРІВ
}

Постановка проблеми. Досягнення мирного співіснування індивідів у суспільстві не можливе без формування відповідної правової культури, створення ефективної, багатогранної та комплексної системи вирішення спорів, підсилення ідеалів примирення у світосприйнятті суспільства та підвищення цінності збереження дружніх відносин. За умов, коли судова система сприймається і по суті є основним методом вирішення правових спорів, суспільство починає втрачати наведені цінності, не тільки перевантажуючи судову систему, але й починає страждати від підвищення рівня конфліктогенності, адже вирішення правових спорів у судовому порядку забирає багато часових і фінансових ресурсів.

Суспільство виробило значний спектр методів вирішення спорів від переговорів, де роль сторін у вирішенні спору $є$ визначальною та відсутні процедурні формальності, до судового розгляду із визначальною роллю суду та процесуальних вимог. При цьому між цими двома прямо протилежними за своїм характером методами є сукупність інших (посередництво, медіація, третейський суд, експертна оцінка, приватний суддя, комісії із розгляду спорів, арбітраж), де роль сторін поступово зменшується на користь третьої особи, а таке широке різноманіття зумовлюється різними потребами сторін спору та унікальністю кожного окремого спору.

Саме мирні процедури вирішення спорів мають бути первинними при виборі варіантів порядку вирішення спорів, починаючи від переговорів, потім із залученням посередника і тільки у випадку неспроможності сторін досягти згоди - залучати арбітра чи суддю. При цьому повинні існувати обгрунтовані та прозорі критерії, зрозумілі для сторін спору, щоб вони змогли зробити правильний вибір щодо того чи іншого методу вирішення спорів для уникнення марнування часу та поглиблення спору через звернення до неефективної процедури. Вагомим може стати посилення ролі суду у сприянні сторонам спору щодо його вирішення в рамках примирних процедур, при цьому судді також мають усвідомлювати й керуватися чіткими орієнтирами у визначенні придатності спорів до вирішення у порядку медіації чи інших видів альтернативного вирішення спорів.
В Україні протягом останніх років триває поступове набуття популярності альтернативними методами вирішення спорів, зокрема, медіацією, продовжується законопроектна робота 3 інституалізації медіації, яка серед іншого полягає у визначенні сфери застосування медіації. Сфера застосування медіації тим не менш не може бути всеосяжною з огляду на суть спору, наявність чи відсутність у спорі інтересів третіх осіб, дієздатність сторін спору та їх суб'єктивне ставлення до вирішення спору у певний спосіб, інші чинники. Вибір сторонами спору порядку його вирішення повинен бути забезпечений не лише інституційно, а й інформаційно. Також має бути забезпечена доступна та обгрунтована інформація щодо критеріїв вибору певних процедур вирішення спорів.

Аналіз останніх досліджень і публікацій. Серед вітчизняних авторів проблематика медіабельності детально вивчалася А. Бортніковою [3] та Н. Мазаракі [4], які зробили свій внесок у юридичну науку, виробивши досить обгрунтовані та чіткі критерії медіабельності спорів, тим не менш приділивши не досить уваги суб'єктивним критеріям. Зарубіжні дослідники, зокрема Г. Кардуччі [8], досліджували критерії медіабельності, базуючись на суттєвому обсязі прикладних досліджень, що дає змогу оцінити підходи до оцінки медіабельності з огляду на розвинуту практику медіації. Однак у науці досі залишається простір до подальших досліджень із вказаної проблематики та розроблення критеріїв медіабельності для їх практичного застосування.

Мета статті - розробити та обгрунтувати класифікацію критеріїв медіабельності спорів.

Виклад основного матеріалу дослідження. Критерії медіабельності спорів, які є предметом нашого дослідження, не можливо розглядати окремо від критеріїв переговорності та арбітрабельності, адже ми вважаємо, що система вирішення спорів у державі повинна бути комплексною та забезпечувати можливість доступу до різних процедур вирішення спорів, а також прийняття сторонами обгрунтованого рішення щодо звернення до тієї чи іншої процедури вирішення спору.

Критерії переговорності були докладно узагальнені Б. Хасаном та Ю. Полещуком, тому ми наводимо результати їх дослідження для форму- 
вання розуміння відмінності критеріїв переговорності від критеріїв медіабельності, яким і приділимо основну увагу в нашому дослідженні:

- сторони повинні мати добру волю до досягнення угоди; якщо хоча б одна зі сторін не розуміє, навіщо їй потрібні переговори, або не хоче їх вести, це означає, що спроби організувати переговорний процес приречені на провал; в особливому випадку потрібно розглядати ситуацію примусу до переговорів, у якій завжди має бути місце перевазі обома сторонами (хоча б тимчасово) переговорного процесу силовому вирішенню конфлікту;

- кожна зі сторін повинна мати власний інтерес у переговорах; саме інтерес (точніше, його задоволеність) є мірою ефективності переговорів; інтереси сторін можуть бути зосереджені як на самому переговорному процесі, так і на тій угоді, якої сторони сподіваються досягти в результаті переговорів; важливо, щоб інтереси сторін не були антагоністичними;

- сторони повинні мати ресурс для виконання домовленостей; якщо переговори закінчуються угодою, а досягнуті угоди не виконуються з посиланням на відсутність ресурсів, то вести мову про власне переговорність безглуздо; саме ресурси визначають серйозність намірів сторін;

- наявна позиційна варіабельність спору в рамках інтересів сторін [1].

Наявність критеріїв переговорності є складником медіабельності, адже за неможливості дійти згоди самостійно, через дію різних чинників сторони звертаються до третьої особи - посередника, медіатора, арбітра. Якщо «не взаємодіяти не можливо, але і взаємодіяти - також, потрібен хтось посередині, той, за допомогою кого вирішується ця тупикова ситуація» [1].

Аналіз праць іноземних та вітчизняних дослідників щодо придатності тих чи інших конфліктів і спорів до вирішення в порядку медіації свідчить про те, що усталеність у суспільстві медіації спонукає дослідників звертати увагу на психологічні особливості сторін спору, характер розвитку певного конфлікту, при цьому дослідники із держав, де медіація перебуває на етапі становлення, шукають визначення критеріїв медіабельності за аналогією з іншими методами вирішення спорів (через категорії арбітрабельності, підвідомчості тощо).

Одне 3 перших вітчизняних визначень критеріїв медіабельності було подано у Проекті примірного положення про Шкільну службу порозуміння (далі - Проект), розробленого групою авторів у 2009 році [2, с. 83]. Так, під критеріями медіабельності було запропоновано розуміти ознаки конфліктної ситуації, які вказують на можливість проведення медіації (наявність принаймні двох осіб, які беруть участь у конфліктній ситуації, ви- знання учасниками ситуації факту конфлікту; наявність фізичної особи, якій було завдано шкоду; наявність контактів сторін).

Також у згаданому Проекті було визначено і функціональне призначення критеріїв медіабельності як передумов до направлення справ i конфліктних ситуацій до медіатора (згідно п. 13 Проекту «Адміністрація закладу освіти, в якому створено Шкільну службу порозуміння, має право направляти справи, які відповідають критеріям медіабельності, до Шкільної служби порозуміння; Адміністрація закладу освіти, в якому створено Шкільну службу порозуміння, зобов'язана сприяти залученню медіаторів служби до розгляду конфліктних ситуацій, які відповідають критеріям медіабельності»).

Досить грунтовне дослідження медіабельності публічно-правових спорів 2017 року провела А. Бортнікова, яка визначила такі критерії: 1) легітимність; 2) законність; 3) спеціальна правосуб'єктність; 4) наявність дискреційних повноважень (адміністративного розсуду) у суб'єкта владних повноважень; 5) компетенційні межі (рамки); 6) спір не зачіпає інтересів осіб, які не беруть участі в медіації; 7) перспектива оформлення результатів медіації згідно з нормами матеріального та процесуального права (так званий критерій дієвості (виконуваності) медіаційної угоди); 8) добровільність [3].

Загалом погоджуючись із запропонованим підходом, ми хотіли б зауважити на доцільності більш чіткого визначення змісту критерію добровільності медіації, адже слід розрізняти реалізацію принципу добровільності при укладенні угоди за результатами медіації та при зверненні сторін спору до медіації. Також критерій дієвості угоди за результатами медіації не є абсолютним, адже медіація як примирна процедура не завжди може завершитися таким позитивним ефектом як досягнення фінальних домовленостей та укладення угоди за результатами медіації. Медіація може забезпечити зниження рівня конфліктності між сторонами, налагодження комунікації, прояснення позицій та інтересів сторін, що навіть за умови подальшого судового розгляду може сприяти його більш швидкому завершенню.

Н. Мазаракі розглядала критерії медіабельності правових спорів у їх взаємозв'язку та певній послідовності, виходячи з умов написання свого дослідження про становлення медіації як правового інституту. Ця авторка запропонувала такі групи критеріїв медіабельності правового спору: 1) які походять із категорії правового спору, правовідносин, з яких виник спір; 2) які залежать від суб'єктного складу сторін спору, а саме дієздатності сторін, наявності відповідних повноважень у представників сторін, можливості участі в медіа- 
ції третіх осіб, права та інтереси яких стосуються суті спору; 3) які визначаються волею сторін іїхнім бажанням вирішити спір у позасудовому порядку.

Ми підтримуємо підхід Н. Мазаракі щодо формулювання таких абсолютних критеріїв немедіабельності спору: 1) наявність прямої законодавчої заборони на вирішення певного виду правового спору в порядку медіації (приклади аналізувалися вище); 2) суперечність предмету й змісту спору моралі та публічному порядку; 3) наявність у споpi інтересів третіх осіб, які не беруть участі в медіації; 4) неможливість укладення мирової угоди згідно із законодавством; 5) недієздатність сторін медіації чи відсутність повноважень їхніх представників на укладання медіаційної угоди [4].

Таке теоретико-правове обгрунтування щодо виключення певних видів спорів зі сфери застосування медіації $€$ необхідним для правильного розуміння меж сфери застосування медіації. Однак вона не надає комплексного та грунтовного розуміння цієї сфери, що вимагає подальших досліджень. Також критерії немедіабельності спорів, розроблені Н. Мазаракі, не враховують того, що не лише факт недієздатності сторін спору має враховуватися, а й наявність істотного дисбалансу сил сторін спору (насамперед, у сімейних спорах), неможливість залучення до медіаційної процедури третіх осіб, які, не будучи безпосередньою стороною спору, мають істотний вплив на волевиявлення сторони медіації та дотримання досягнутих домовленостей.

Зміст і сутність категорії немедіабельності були досить грунтовно розтлумачені в англійській судовій практиці. Зокрема, при обгрунтуванні підстав відмови у зверненні до процедури медіації у справі Halsey v Milton Keynes General NHS Trust суд вказав на такі аспекти: суть спору (зокрема, суд вказав, що «за своєї суттю більшість спорів не є непридатними для медіації»); позиції сторони у спорі, зокрема, сторона спору, яка вважає, що має сильні позиції й обгрунтовано може бажати саме судового розгляду; попередні спроби вирішити спір у мирний спосіб; непропорційно високі витрати на медіацію; застосування медіації призведе до затримки судового розгляду; відсутність чітких підстав сподіватися на успіх медіації [5].

Автори підручника «Медіація» підкреслюють, що медіабельність має два показники: 1) властивість конфлікту, яка визначає можливість роботи 3 ним за допомогою медіації; 2) критерій ефективності результату медіації, який визначає відсутність постконфлікту та можливість виконати досягнуті домовленості [8]. Врахування другого показника свідчить про те, що критерії медіабельності не можливо розглядати виключно в юридичній площині, необхідно враховувати суб'єктивні чинники та ставлення сторін до перспектив участі у медіації та її результативного завершення.
Так, Х. Бесемер [7] стверджує, що медіація не замінює інших форм вирішення конфлікту й доцільна в обмеженій кількості випадків: незадовільні спроби безпосередніх переговорів; зацікавленість у перспективі відносин; прагнення всіх учасників конфлікту до угоди; ситуація, коли представлені в конфлікті інтереси не стосуються принципових цінностей; відносна рівність сторін у питаннях влади; достатній ресурс часу для вироблення угоди; відсутність яскраво виражених перешкод психологічного або правового характеру.

Комплексним та унікальним видається дослідження Г. Кардуччі [8] щодо важливості юридичного контексту та інших чинників при оцінці придатності переговорів, медіації, арбітражу та судочинства для ефективного вирішення внутрішніх і міжнародних спорів. Під «контекстом» вказаний автор пропонує розуміти факти та правові норми, які визначають безпосередньо спір і процедурні правила медіації, арбітражу, судочинства. 3 огляду на різноманіття правових спорів щодо їх предмету, складності, характеру (внутрішньодержавний чи міжнародний, правовий статус і кількість сторін спору) та ціни, Г. Кардуччі спробував у формулюванні критеріїв медіабельності зважати на такі особливості спорів і сторін спору:

1) необхідність знання вузькоспеціалізованих правових норл при вирішенні правового спору. Г. Кардуччі підкреслює, що цей критерій не є абсолютним і нестача вузькоспеціалізованих знань може бути компенсована залученням експерта. Основною ж метою діяльності медіатора є сприяння проведенню переговорів між сторонами, а не визначення порядку застосування правових норм;

2) застосовне право чи інші міркування. Г. Кардуччі пропонує враховувати важливість для сторін чиннику збереження відносин чи отримання компенсації, захисту прав в рамках застосування норм права. У цьому ж контексті автор розмірковує, що позиції сторони у спорі можуть бути «слабкими» $з$ точку зору застосовного права, водночас суть спору може включати й інші елементи, які сприятимуть більш вигідному результату вирішення спору у порядку медіації, а не судочинства;

3) національні та міжнародні спори. Г. Кардуччі обгрунтовує, що національний спір (спір за відсутності іноземного елементу) є більш прогнозованим і легким для вирішення, на відміну від міжнародних спорів (з іноземним елементом), тому цей аспект суті спору має бути детально врахованим сторонами спору при прийнятті рішення про спосіб його вирішення;

4) суть спору, юридичний контекст та ї відношення до визначення відповідного механізму вирішення спорів. Аналізуючи такий критерій, Г. Кардуччі наводить приклад із трудовими спорами, доходячи висновку, що у разі, якщо національне законодавство робить працівника 
«сильною стороною спору», то за його бажання максимально захистити свої права йому необхідно звертатися до суду, тому що медіація та арбітраж, пропонуючи менш конфронтаційний і більш дружній механізм спору, можуть все ж таки не забезпечити максимального результату. Також до юридичного контексту як критерію обрання того чи іншого механізму вирішення спорів Г. Кардуччі відносить правовий статус угоди за результатами вирішення спорів, адже остання $€$ «фінальною» у вирішенні спорів лише за умови наявності в національному законодавстві порядку приведення до виконання угод за результатами вирішення спорів;

5) сторонал спору необхідне вирішення спору, колпенсація чи судове рішення, яке можна привести у виконання в іншій державі. На час підготовки дослідження Г. Кардуччі у 2012 році ще не було навіть розпочато роботи над Конвенцією ООН про міжнародні угоди про врегулювання спорів за результатами медіації, тому ми можемо припустити, що висновки автора не є актуальними нині. Тим не менш вони підкреслюють доцільність підписання вказаної Конвенції як запоруки подальшого розвитку міжнародної комерційної медіації. 3 огляду на обмежену сферу застосування конвенції, висновки Г. Кардуччі щодо переваг арбітражу та судочинства у певних спорах, в яких сторонам необхідне саме судове чи арбітражне рішення, є слушними;

6) час, фінансові витрати, конфіденційність.

Проаналізувавши підхід італійського дослідника до визначення критеріїв медіабельності спору в розрізі визначення аспектів, якими мають керуватися сторони спору при обранні того чи іншого механізму вирішення спорів, ми погоджуємося, що критерії мають братися до уваги у взаємозв'язку з урахуванням дійсних потреб сторін спору та їхніх очікувань від порядку та результату його вирішення. Адже суто теоретичне порівняння характеристик механізмів вирішення спорів має лише пізнавальну та дослідницьку функції, водночас кожен окремий спір є унікальним, а сторони спору, їхні представники, медіатор мають зробити власне обгрунтоване рішення щодо медіабельності чи немедіабельності з метою якнайкращого захисту прав та інтересів фізичних та юридичних осіб.

На основі проведеного аналізу наукових джерел, методичних матеріалів міжнародних організацій, зарубіжної судової практики, а також чинного законодавства України ми виробили власне бачення критеріїв медіабельності спорів і для їх цілісного сприйняття об'єднали у певні групи: сталі критерії, вплив яких виключає ложливість проведення ледіацї; злінні критерії, межі впливу яких на медіабельність спору ложуть варіюватися в результаті роботи медіатора, представників сторін спору та корегування зовнішніх обставин тощо. Для кращого розуміння сутності як медіаційної процедури, так і категорії медіабельності спору ми пропонуємо виділяти:

1) змінні критерії, які підвищують вірогідність початку медіаційної процедури та її результативного завершення;

2) змінні критерії, які знижують вірогідність початку медіаційної процедури та її результативного завершення;

3) змінні критерії, пов'язані із суб'єктивним ставленням певного медіатора до оцінки медіабельності певного спору.

До групи сталих критеріїв медіабельності правових спорів пропонуємо відносити:

- неможливість проведення процедури медіації певного виду правового спору згідно національного законодавства, що може полягати у виключенні певних видів спорів зі сфери застосування медіації, неможливості укладення мирової угоди в певних категоріях спорів, у випадках насильства в сім'ї, торгівлі людьми, жорстокого поводження з дітьми;

- наявність у спорі прав та законних інтересів третіх осіб, які не беруть участі в медіації;

- неможливість дотримання принципу самовизначення сторін спору, наприклад, через повну чи часткову недієздатність сторони спору, значний дисбаланс сил, який не можливо компенсувати під час процедури медіації;

- недоговороспроможність сторін як характерна риса хоча б однієї зі сторін конфлікту.

Змінні критерії, які підвищують вірогідність початку медіаційної процедури та її результативного завершення: сторони спору схильні до вирішення спору у позасудовий спосіб чи мають досвід участі в медіації; сторони спору мають негативний досвід вирішення спорів у судовому порядку чи мають досвід неможливості виконання судового рішення; передбачувані високі витрати на судовий розгляд, залучення адвокатів, експертів; передбачуваний тривалий судовий розгляд спору; позитивне ставлення адвокатів сторін до медіації; бажання сторін забезпечити конфіденційність самого факту спору, його суті, пов'язані 3 цим репутаційні ризики; сторонам необхідний результат, який не може забезпечити судове рішення; сторони перебувають у тривалих відносинах і бажають їх зберегти; суть спору виходить за межі правового спору; неоднозначність правової позиції сторони; сторонам важливо дійти тривалого, сталого рішення; у сторін є різне тлумачення та розуміння юридичних фактів, бачення обставин справи; сторонам спору необхідно виявити накопичені емоції; стороні спору необхідно бути почутою іншою стороною; сторони та їхні адвокати вже не можуть ефективно комунікувати між собою без допомоги посеред- 
ника; готовність брати на себе відповідальність за вирішення спору; бажання з'ясувати причини виникнення спору (непорозумінь); бажання попередити виникнення конфлікту чи його ескалації.

Змінні критерії, які знижують вірогідність початку медіаційної процедури та її результативного завершення: сторони не схильні до співробітництва та розуміння одна одної; сторони перебувають у тривалому конфлікті, що досягнув такої стадії ескалації, яка унеможливлює медіацію; спір є багатоаспектним, і сторони ще не досягли взаємовигідного рішення за жодним аспектом; високий рівень ворожості між сторонами спору; відсутність довіри між сторонами спору; сторони спору схильні та мають досвід вирішення спорів і конфліктів силою; значний дисбаланс сил; загроза фізичному чи психологічному здоров'ю однієї сторони спору з боку іншої сторони; до конфлікту (спору) залучені інші особи, окрім позивача та відповідача; сторонам спору необхідно вжити заходів забезпечення позову (ми відносимо цей аспект до групи змінних, адже після вжиття судом заходів забезпечення позову сторони спору можуть розпочати медіацію); у сторони / сторін спору є попередній негативний досвід участі в медіації; сторона спору будує свою репутацію як таку, яка завжди принципово відстоює свою позицію в судових процесах; сторонам спору необхідне вирішення спору, компенсація чи судове рішення, яке можливо привести у виконання в іншій державі, наприклад, у порядку, передбаченому Конвенцією ООН про міжнародні угоди про врегулювання спору за результатами медіації; право, яке регулює спірні правовідносини, може забезпечити кращі умови вирішення спору для однієї зі сторін; відсутність довіри сторін внаслідок недотримання попередніх домовленостей, досягнутих за результатами прямих переговорів; потреба в публічності, гласності вирішення спору.

Висновки. Під медіабельністю спору слід розуміти сукупність ознак конкретного спору, дієздатності та суб’єктивного ставлення сторін спору, можливості дотримання принципів медіації у певній медіаційній процедурі, які визначають об’єктивну та суб'єктивну можливість проведення медіаційної процедури та впливають на вірогідність ïi результативності. Розробка чітких та обгрунтованих критеріїв медіабельності спору є запорукою ефективного становлення медіації як альтернативного методу вирішення спорів, формування довіри суспільства до медіації через розуміння ii сутності та природи.

\section{Jimepamypa}

1. Хасан Б., Полещук Ю. Критерии медиабельности конфликтов в юридической практике. Вестник СПбГУ. Серия 14. Право. 2020. № 1. С. 207-222.

2. Головатий В., Горова А., Коваль Р., Синюшко М., Семчишин О., Шидловська Л. Стратегії забезпечення життєздатності відновних практик: механізм співпраці правової системи та громади заради суспільної безпеки : посібник. Київ, 2009. 224 с.

3. Бортнікова А. Критерії медіабельності публічноправового спору. Visegrad journal on human rights. 2017. № 6. URL: http://vjhr.sk/ archive/2017_6/5.pdf (дата звернення: 30.01.2021).

4. Мазаракі Н. Щодо поняття медіабельності спору. Підприємництво, господарство і право. 2018. № 12. C. 258-262.

5. Halsey v Milton Keynes General NHS Trust [2004] EWCA Civ 576. URL: http://www.bailii.org/ ew/cases/EWCA/Civ/2004/576.html (дата звернення: 30.01.2021).

6. Медиация : учебник / Под ред. А. Карпенко, А. Осиновского. Москва, 2016. 470 с.

7. Бесемер Х. Медиация. Посредничество в конфликтах. Калуга, 2005. 176 с.

8. Carducci G. The importance of legal context and other considerations in assessing the suitability of negotiation, mediation, arbitration and litigation in resolving effectively domestic and international disputes (employment disputes and beyond). St. John's Law Review. 2012. № 86(2). C. 511-541.

9. Державний стандарт соціальної послуги посередництва (медіації) : наказ Міністерства соціальної політики від 17.08.2016 № 892. URL: https://zakon.rada. gov.ua/laws/show/z1243-16\#Text (дата звернення: 30.01.2021).

\section{Анотація}

Романадзе Л. Д. Критерії медіабельності в контексті системи вирішення спорів. - Стаття.

В Україні останніми роками триває поступове набуття популярності альтернативними методами вирішення спорів, зокрема, медіацією, продовжується законопроектна робота з інституалізації медіації, яка серед іншого полягає у визначенні сфери застосування медіації. Сфера застосування медіації тим не менш не може бути всеосяжною з огляду на суть спору, наявність чи відсутність у спорі інтересів третіх осіб, дієздатність сторін спору та їх суб'єктивного ставлення до вирішення спору у певний спосіб, інші чинники.

Вибір сторонами спору порядку його вирішення повинен бути забезпечений не тільки інституційно, також має бути забезпечена доступна та обгрунтована інформація щодо критеріїв вибору певних процедур вирішення спорів. Розробка чітких та обгрунтованих критеріїв медіабельності спору є запорукою ефективного становлення медіації як альтернативного методу вирішення спорів, формування довіри суспільства до медіації через розуміння її сутності та природи. Під медіабельністю спору слід розуміти сукупність ознак конкретного спору, дієздатності та суб'єктивного ставлення сторін спору, можливість дотримання принципів медіації у певній медіаційній процедурі, які визначають об'єктивну та суб'єктивну можливість проведення медіаційної процедури та впливають на вірогідність їі результативності.

На основі проведеного аналізу сформульовано критеріїї медіабельності спорів: сталі критерії, вплив яких виключає можливість проведення медіації; змінні критерії, межі впливу яких на медіабельність спору можуть варіюватися в результаті роботи медіатора, представників сторін спору та корегування зовнішніх обставин. Для кращого розуміння сутності як медіаційної процедури, так і категорії медіабельності спору пропонується виділяти змінні критерії, які підвищують вірогідність початку медіаційної процедури та її результативного завершення; змінні критерії, які зни- 
жують вірогідність початку медіаційної процедури та iї результативного завершення; змінні критерії, пов'язані із суб'єктивним ставленням певного медіатора до оцінки медіабельності певного спору.

Ключові слова: медіація, медіабельність, медіатор, критерії медіабельності, альтернативні методи вирішення спорів.

\section{Summary}

Romanadze L. D. Criteria of mediability in the context of the dispute resolution system. - Article.

In recent years, alternative methods of dispute resolution are gradually gaining popularity in Ukraine, in particular, mediation and bill work on the institutionalization of mediation, which, among other things, is to determine the scope of mediation. However, the scope of mediation cannot be comprehensive given the nature of the dispute, the presence or absence of third party interests, the capacity of the parties to the dispute and their subjective attitude to resolving the dispute in a certain way and other factors. The choice of the parties to the dispute should be ensured not only institutionally, but also should be provided with accessible and reasonable information on the criteria for selecting certain dispute resolution procedures.

The development of clear and sound criteria for the mediability of the dispute is the key to the effective devel- opment of mediation as an alternative method of dispute resolution, the formation of public confidence in mediation through an understanding of its essence and nature. The mediability of the dispute should be understood as a set of features of a particular dispute, capacity and subjective attitude of the parties to the dispute, the possibility of compliance with the principles of mediation in a particular mediation procedure, which together determine the objective and subjective possibility of mediation.

On the basis of the conducted analysis the criteria of mediability of disputes are formulated: constant criteria, the influence of which excludes the possibility of mediation; variable criteria, the limits of which on the mediability of the dispute may vary as a result of the work of the mediator, representatives of the parties to the dispute and the adjustment of external circumstances, etc. In turn, to better understand the essence of both the mediation procedure and the category of mediability of the dispute, it is proposed to identify: variable criteria that increase the probability of the beginning of the mediation procedure and its effective completion; variable criteria that reduce the probability of initiating a mediation procedure and its successful completion variable criteria related to the subjective attitude of a particular mediator to the assessment of the mediability of a particular dispute.

Key words: mediation, mediability, mediator, mediability criteria, alternative methods of dispute resolution. 